\title{
New challenges for Social Psychology in Brazil
}

\author{
Willem Doise \\ University of Geneva
}

\begin{abstract}
In this paper we analysed the variety of contemporary social psychological approaches in Brazil as part of a network and of a complex common scientific system. They mutually influence each other in different ways, according to intricate patterns of approach and avoidance, of confirming agreements in various ways and, of course, also accentuating disagreements. The paper suggests that such intervention could further a mutual discussion on the role that social psychologists could play or not in the process of societal change that characterizes the Brazilian society, and on how they eventually should or should not intervene in this change. In order to dynamize even more the social psychology community in Brazil, the idea of Summer Schools could be recommended.
\end{abstract}

Keywords: Social Psychology; socio-cognitive conflict; social influence.

\section{Resumo}

Novos desafios para a Psicologia Social no Brasil. Neste artigo analisamos a variedade das abordagens contemporâneas da psicologia social no Brasil como parte de uma rede e de um complexo sistema científico comum. Eles se influenciam mutuamente de diferentes maneiras, de acordo com intrincados padrões de aproximação e esquiva, confirmando acordos de vários tipos e, é claro, também acentuando as divergências. $\mathrm{O}$ artigo sugere que tal simpósio poderia promover uma discussão sobre o papel dos psicólogos sociais no processo de mudança social que caracteriza a sociedade brasileira e, eventualmente, como eles poderiam intervir nesta mudança. A fim de dinamizar ainda mais a comunidade da Psicologia Social no Brasil, a idéia de Escolas de Verão poderia ser recomendada.

Palavras-chave: Psicologia Social, conflitos sociocognitivos, influência social.

$\mathrm{W}$ hile reading the contributions to a recent symposium on Os rumos da Psicologia Social no Brasil at the University of Brasilia (October 9 to 11, 2012) I was very impressed by the variety of contemporary social psychological approaches that thrive in Brazil. These schools should be analyzed as part of a network and of a complex common scientific system. This does not mean that all departments of social psychology are collaborating with every other department, but there is no doubt that they now mutually influence each other in different ways, according to intricate patterns of approach and avoidance, of confirming agreements in various ways and, of course, also accentuating disagreements.

Influence patterns across group or subgroup boundaries are complex. As the old dictum has: "Fas est ab hoste doceri" (Ovidius), one can learn from the opponent. Such learning is based on interpretations or conjectures about the reasons why colleagues agree or disagree, which are rarely explicated. Such ways of understanding or even misunderstanding are to be considered as important aspects of ongoing scientific debates in academic communities. Mutual influences cannot be reduced to simple processes; also in the scientific world these are to be studied as social dynamics shaped in complex settings of inter- and cross-group relations. Of course for some Brazilian social psychologists the main out-group may be the "North Americans", but certainly Brazilian colleagues do also participate in patterns of socio-cognitive conflict with other Brazilians.

How can an outsider intervene in such a complex situation? I would suggest that such an intervention could exist in furthering a mutual discussion on the role that social psychologists could play or not in the process of societal change that characterizes the Brazilian society, and on how they eventually should or should not intervene in this change. The organization of such a discussion could become a common goal in the sense of Muzafer Sherif (1966). Certainly the purpose is not to develop a common view on such a controversial issue, but to try to understand the reasons of a different positioning towards this general issue. Usually according to the very logic of scientific thinking, many social psychologists tend to adhere to a deterministic world view, and in this sense they may adhere to the idea that they could only intervene in furthering rather adaptive and submissive attitudes towards ongoing social developments. However, other social psychologists adhering to alternative and more voluntaristic societal conceptions could also think that highlighting the gap between important social expectations and existing social 
realities can create a kind of socio-cognitive conflict, resulting in important social changes. Such a positioning may be adhered to by social psychologists who cherish a less fatalistic and more constructive conception of their academic activity.

\section{On minority influence and social change}

At the beginning of Serge Moscovici's minority influence theory, his doctoral students S. Madoglou, G. Mugny, S. Papastamou (see Mugny \& Papastamou, 1981), proposed in the initial presentation of their research, and in some subsequent publications, societal theories opposing "active" minorities to powerful majorities. "Activists" were supposed to influence masses of people who adhered to a dominant ideology. They elaborated conceptions of society that opposed minority views to dominant ideologies, and studied the conditions in which the former could prevail over the latter. Sometimes explicit references were made to a Marxist conception of society.

In Moscovici's (1976) book, Social Influence and Social Change, societal concerns remain present, but often majority/ minority relations were thereafter defined in mere numerical terms. Hence, a less "radical" conception of minority/majority relations circulated and may have contributed to a kind of "internationalization" of the theory, contrary to what happened in the realm of social representations studies - another research area initiated by Serge Moscovici (Smith, 2005). In a certain sense, experimental influence models became more neutral from a societal perspective; in any case more so than social representation research paradigms. This may be the reason why social representation studies are often not presented in "mainstream" English language social psychology handbooks. Apparently this is not yet the case in Brazil, where various positions find their place in more pluralistic textbooks (Camino, Torres, Lima, \& Pereira, 2011). Apparently, also in Brazil active minorities are present in the field of contemporary social psychology, as well.

\section{The importance of social justice concerns for produc- ing social change}

I will now argue that, especially where concerns about existing social injustice become salient, critical societal approaches are generated, also in the scientific field of social psychology. In such cases, at least some scientists become aware that they are not just "neutral" observers of social reality. Their intellectual positioning means they have to participate in efforts to change society, to make social reality evolve, and to contribute in an effort to have social justice principles respected. The need for social change produces social psychologists perhaps more than social psychologists can produce social change.

Let us consider issues of social discrimination. It is now well known that North American social psychologists as Otto Klineberg actively intervened in the issue of racial discrimination at Brown v. Board of Education in the fifties of last century (Kluger, 1975). Later Susan Fiske denounced gender discrimination in the Court case of Ann Hopkins versus Price-Waterhouse Coopers (Fiske, Bersoff, Borgida, Deaux, \& Heilman, 1991). Abuse of power by the highest American political authorities was denounced by Zimbardo (2007) when he intervened in the Abu Graib scandal, and argued that political authorities, and not so much prison guards, were at the origin of these abuses.

These "American" social psychologists intervened at a juridical level and became influential in processes of societal change. The results of their effort showed in a certain way that social psychology research on societal issues can contribute effectively to social change, hence become influential in combating discrimination. It is to be considered that at certain historical moments the concerns about social justice are developed in a society, and that social psychologists share these concerns. Their understanding of an evolving social reality makes them contribute to the effort of changing this reality, making them participate in the dynamics of social change. Their scientific activity aiming at understanding an unjust social reality may also result in efforts to change this reality, for instance in the realm of studying gender differences.

\section{Interdisciplinary and international dimensions}

The so-called American social psychology is now part of the scientific field of social research all over the world. It is obvious that the Brazilian social psychologists are aware of this international dimension of their scientific endeavour, and it is not longer a matter of such an intense debate as it was in Europe forty years ago (Israel \& Tajfel, 1972).

There is yet another broadening of scientific sociopsychological field boundaries, but perhaps not as evidently as the international one, at least in the scientific publications I was able to read or re-read for preparing my participation in the above mentioned symposium. It is the interdisciplinary dimension. In the numerous scientific activities in which I could take part in Brazil, references to sociologists, anthropologists, historians or other social scientists are rather exceptional. This is not a specific characteristic of the Brazilian social psychological community, but maybe in this country such a concern is less often expressed than in some European countries.

In order to provide an example of an interdisciplinary broadening of the field, I shall just deal here with the necessity of cultivating links with the community of educational scientists, especially in a period of social change.

\section{Pedagogy and societal change}

Protagonists of many important social movements consider it necessary to reshape educational practices so that individuals would be able to cooperate in installing a new social order. This was the case when in December 26, 1919, Vladimir Lenin inaugurated a new policy of liquidation of illiteracy and established a system of compulsory education for all children. In quite different circumstances, Piaget (1932), the author of the Moral Judgment, pleaded for a more democratic education and became the Chairman of the International Bureau of Education. When in the early seventies of last century the democratic regime was re-installed in Portugal, the professoral staff of Psychology department of the Geneva University was invited in corpore to Lisbon by protagonists of the revolution, in order to discuss with them the possible educational innovation that could be launched on the basis of Piagets' theory. 
More recently, protagonists of the ecological social movement have also forwarded a plea for innovating educational practices. In Rabhi's (2008) recent Manifesto for recognition of the environment rights to be respected, as well and perhaps even more than the rights of humans to live in a healthy environment, on three different places arguments are advanced in favour of specific changes in educational practices. According to a first plea, more ecological educational practices should further in the youth attitudes of solidarity and cooperation instead of competition, establish more balanced relations between males and females, and generally respect equally all creatures. Further in the Manifesto a new ethic is promoted based on cultivating modesty and honesty, rather than on accumulating property. And finally on a third place individuals are reminded of the importance of fighting consumerism and fatalism, and of the necessity of holding themselves also responsible for the actual ecological situation.

These historical examples clearly show how important social movements envisage only a successful issue for their cause if educational practices are changed. This was indeed the case in Portugal after the fall of the dictatorial regime in the seventies.

\section{Linguistic pluralism}

The award of preeminence to the English language in Europe is now commonly and uncritically accepted as a suitable measure for overcoming tensions between the exigency of universalism and the interference of more "local" conditions. Of course such a tendency is reinforced by the fact that main publications in European social psychology are edited by publishers based in Great Britain.

Unfortunately, in the present context the "higher" status of mainstream English language journals often results in homogenisation and not universality or pluralism in scientific thinking. I will not summarize here the growing consensus on that topic, but reproduce two quotations from an article by Peter B. Smith (2005) who explains why social representation theory has remained an "indigenous European" social psychology, whereas social identity and minority influence theories became more internationalized. Indeed the latter two theories became highly influenced by the "transatlantic traffic": "Evaluation of research productivity among European researchers is typically based upon their success in publishing their work in APA journals. In the UK, an individual's high rating in their periodic assessment of research productivity is based upon publication in 'international' (i.e., APA) journals. In the interuniversity consortium of Dutch social psychologists, known as the Kurt Lewin Institute, similar criteria are applied. Thus the design and conduct of studies is often undertaken with forethought given to the likely response of US reviewers to a journal submission. The greater appeal of the theory of social representations further south may reflect a lesser dependence on such criteria in these nations, and a stronger emphasis on training in more qualitative modes of data analysis" (Smith, 2005, p. 260). Social representation theory so far avoided merging with transatlantic theories:

because of a greater preponderance of publication in languages other than English, and partly because of the preference for publication in books rather than journals. The theory of social representations currently commands much greater attention in Latin America, particularly in Brazil than it does in North America. (Smith, p. 260).

Merging of theories across national borders is a necessity, but not at the cost of loosing scientific creativity and originality as it is now the case according to P. B. Smith. To avoid such loss, national networks should be maintained and furthered, which unfortunately is not the present policy of the European Association of Social Psychology.

Shall the Brazilian social psychologists follow the same way and jump on the Anglo-Saxon bandwagon?

\section{The temporal dimension}

Scientific communities are historical entities. Their daily work is to revisit the heritage of the past, exploiting it further and transforming it. This is of course a collective endeavour and each new approach has to be defined by its initiators in relation to relevant past and present contributions. At each epoch approaches of classical theoretical problems are redefined. What was once considered by authors as Adorno (Adorno, Frenkel-Brunswik, Levinsons, \& Sanford, 1950) as a syndrome of The Authoritarian Personality in a given societal context is now studied as a manifestation of a social dominance orientation (Sidanius, 1999) or as a justification of a given social order (Jost \& Banaji, 1994). How should a researcher decide on the explanatory models that $\mathrm{s}$ / he takes into consideration, and more specifically how far in the past should s/he go back to retrieve explanatory models. For this issue also the proof of the pudding is in the eating, it is a matter of retrieving the more powerful explanatory systems. However research is above all a collective enterprise and, at least in my view, the theoretical positioning of a researcher cannot avoid taking into consideration available contemporary explanatory approaches, even if it were only to invalidate them. This involves explicit positioning toward other relevant positioning present in the contemporary international research community, but certainly also toward diverse positioning in one's own national community, especially when this community is now so rich and diverse as is now the Brazilian one.

Taking into account a temporal dimension always results in a kind of trade off between references to the scientific past and references to the present and possible future state of the scientific field. The bigger the scientific community, the more this positioning should involve contemporary colleagues.

\section{To conclude}

I have already dealt with pedagogical concerns that militants of social movements generally consider important. Let me now apply this pedagogical concern for furthering in Brazil the advancement of social psychological research. More senior members should for sure be involved in this cause. However this cause also involves socialization processes of younger future colleagues. Therefore, I reactualize at this occasion a pedagogical initiative that was suggested last year at a meeting in Brasilia. In order to dynamize even more the social psychology 
community in Brazil, the idea of Summer Schools should again be recommended. In the European Association of Social Psychology these schools have been a very important factor for developing social psychological research in Europe, even when Europe was still divided by the Berlin Wall. In such meetings, both senior social psychologists and postdoctoral students review together research areas and develop new research projects. Nowadays some of these activities could probably also take place through electronic exchanges.

\section{References}

Adorno, T., Frenkel-Brunswik, E., Levinsons, D. J., \& Sanford, R. N. (1950) The authoritarian personality. New York: Harper and Row.

Camino, L., Torres, A. R. R., Lima, M. E. O., \& Pereira, M. E. (2011). Psicologia Social : Temas e teorias. Brasilia: Technopolitik.

Fiske, S. T., Bersoff, D. N., Borgida, E., Deaux, K., \& Heilman, M. E. (1991). Social science research on trial: Use of sex stereotyping research in Price Waterhouse v. Hopkins. American Psychologist, 46, 1049-1060.

Israel, J., \& Tajfel, H. (1972). The context of Social Psychology: A critical assessment. London: Academic Press.

Jost, J., \& Banaji, M. (1994). The role of stereotyping in system-justification and the production of false consciousness. British journal of Social Psychology, $33,1-27$.

Kluger, R. (1975). Simple justice: The history of Brown v. Board of education and black America's struggle for equality. New York: Knopf.

Moscovici, S. (1976). Social influence and social change. London: Academic Press.

Mugny, G., \& Papastamou, S. (1981). El poder de las minorias. Barcelona: Ediciones Rol.

Piaget, J. (1932). Le jugement moral chez l'enfant. Paris: Delachaux et Niestlé. Rabhi, P. (2008). Manifeste pour la Terre et l'Humanisme. Arles: Actes Sud.

Sherif, M. (1966). In common predicament: Social psychology of intergroup conflict and cooperation. Boston: Houghton Mifflin.

Sidanius, J. (1999). Social dominance: An intergroup theory of social hierarchy and oppression. New York: Cambridge University Press.

Smith, B. P. (2005). Is there an indigenous European Social Psychology? International Journal of Psychology, 40(4), 254-262.

Zimbardo, P. (2007). The Lucifer effect. Understanding how good people turn evil. New York: Random House.

Willem Doise, honorary professor at the University of Geneva, Switzerland. Sponsored by the Coordination for the Improvement of Higher Level -or Education- Personnel (CAPES) and University of Brasília. E-mail: Willem.Doise@unige.ch 